\title{
THE TRADITIONS OF THE IRISH BARDS IN THE CONTEXT OF SOCIOCULTURAL DIVERSITY
}

\author{
Sokolova A. V.
}

\section{INTRODUCTION}

Irish identity is built on the concept of the individual and the personal. A free man was the owner of his land and home, in turn, the Irish house was not only his property, but also a kind of fortress, the entrance to the territory of which was strictly prohibited. The collection of Irish families or the Irish clan was considered a sovereign and independent unit, families belonging to an Irish clan chose their leaders.

Relations with the leader of the clan were put at the forefront, since the status of a man or woman, the possibility of career advancement, successful marriage, prestigious military service, was determined exclusively by relations with the clan leader. Such a strict hierarchy left an imprint on the original culture of Ireland in all its fields.

It was believed that the poetry and music of the Irish was an integral part of Irish life. The Irish were intoxicated by the power of word and sound! Irish poetry is a kind of mixture of complex rhythmic patterns, metaphors, and symbols. The Irish style was different from the poetic traditions of other ethnic groups and did not change for centuries.

In ancient Irish society, the priest's druids, filid, and bards were the core of Celtic-Irish society and could be regarded as the holy Trinity of the preChristian pagan period.

The bard is a symbol of Ireland, the voice of the nation. The origins of this attitude are rooted in the work of the English poet of the XVIII century sentimentalist Thomas Gray, who wrote the ode "Bard" in 1757. T. Gray determines the role and status of the bard by the level of his education. The concept of "bard is equal to a poet" is equivalent to each other and lies in the same plane. However, the concept of "poet equals bard" cannot always be considered in a single bundle ${ }^{1}$.

The poetry of the bards is a complex poetic tradition of the oral sense, preserved for a long period during the heyday of the Irish language and culture until the second half of the seventeenth century.

Music played an important part in the life of bards. Refined musical taste was inherent in the original inhabitants of this island, gradually improving with the development of Irish society. Every Irish hero, every virgin had to touch the harp at least once in her life. The ability to play musical instruments

${ }^{1}$ Grey T. Elegy Written in a Country Churchyard. Charleston : Nabu Press. 2012. 94 p. 
demonstrated the degree of human education. It was believed that music has healing properties that can heal the soul and physical body of a person from ailments. The peculiarity of ancient Irish music lies in its cardinal difference from music of other nationalities. The human ear is always able to distinguish specific Irish music from any other.

The Irish admiration for poetry and music was great. Even after the Irish renounced paganism, the disappearance of the Order of the druids, conversion to Christianity and attempts to prohibit the activities of the bards, they adapted to the rapidly changing reality and experienced the flourishing of their creative activity. The historical evidence of the bards left by the ancient Greek historians Strabo and Diodorus Siculus suggested that the traditions of the bards, who lived in Ireland and in the north of Scotland in antiquity and during the Middle Ages, remained unchanged for many centuries ${ }^{2}$.

\section{The filid traditions as part of the phenomenon of Irish culture}

The filid occupied an important social position in Ireland, similar to the role of Bedouin poets in pre-Islamic Arabia. The filid were poets, but not songwriters, singers, or musicians ${ }^{3}$. The filid studied for about twenty years. The filid were perfectly oriented in poetic rhyming, in composition, in the art of prophecy and foresight, knew epic legends and genealogies of Irish kings by heart ${ }^{4}$. At the end of the training, the best of the filid received the honorary title of Allam or Teacher. Allam had an impeccable reputation. Allam was granted a salary of 20 cattle, relying on "an unlimited estate and free rent," "owning property outside his own home", a retinue of 24 people who served as servants. To all that was enumerated, the official status of the King's poet was assigned to the filid-Ollam, which in fact was equated with the status of a king, which terrified the English aristocracy of the era of Queen Elizabeth I. The Gaelic kings not only sat at the same table with their court poets, but also had a meal with them, using the same dinner service. The filid of the King were initiated into all political issues and national security issues. The duty of the filid was to take care of their patrons. Each bard was to instruct his patron. Fillid is a special position, by right, the king paid the most attention to him, and Fillid surrounded his patron with attention and love ${ }^{6}$. The Irish did not practice corporal or capital punishment. The punishment for the deed was limited to the payment of a fine, the amount of which varied depending on the

\footnotetext{
${ }^{2}$ Cooper J. Walker Historical Memoirs of The Irish Bards: An Historical Essay On The Dress Of The Ancient And Modern Irish, And A Memoir On The Armour And Weapons Of The Irish. Mishawaka : Palala Press. 2015. 514 p.

${ }^{3}$ Llywelyn M. Bard: The Odyssey of the Irish. New York : Tor Books. 1987. 480 p.

${ }^{4}$ Greene D. Duanaire Mheig Uidhir: the Poembook of Cu Chonnacht Mag Uidhir, Lord of Fermanagh 1566- 1589, Edited from the Copenhagen. Vol 1. 1991. 307 p.

${ }_{6}^{5}$ Green M.J. Dictionary of Celtic Myth and Legend. London : Thames and Hudson. 1997. Pp. 80-179.

${ }^{6}$ Carney J. The Irish Bardic Poet: a Study in the Relationship of Poet and Patron as Exemplified in the Persons of the Poet, Eochaidh O Heoghusa (O’Hussey) and ... of Fermanagh. Dublin : Dublin Institute for Advanced Studies. 1985. 40 p.
} 
gravity of the crime. So, if Ollam was insulted, humiliated, or caused physical harm to him, the offender was punished by confiscation of his property.

The role of the filid in Celtic-Irish society remains an unexplored question: "Were they an offshoot of the sacred priests of the druids or were they a completely separate group?" However, it is known for certain that despite the gift of foreseeing the future, the filid, unlike the druids, were focused on the material, and not on the spiritual world. The filid, having undoubted merits, talents and merits, gradually turned into court poets, advisers and privileged actors, whose services were highly paid. So, theatrical practice (Reacaire) is well known, when the filid read the composition in a recitative style to the king to the sounds of instrumental harp music. In general, the division of roles between the poet, reader, and musician meant that one composed a ballad, the other played the harp, and the third acted as a reader. The person who was responsible for reading the poem to the leader was called a reader. His pronunciation should have been perfect. Reading was usually accompanied by instrumental music. A filid acted as a mentor, spoke very little, but made sure that everyone present did their job at a good level. Poems that were recited to the sounds of instrumental music and extolled the virtues of the Kings, reinforcing the "image" of a man of noble origin, possessing generosity, and courage. When Kings heroically died in battle or died naturally, the "stones of his glory" were picked up by bards and immortalized in poems abounding with epithets that were passed down from generation to generation. There was a belief: if the hero is undeservedly forgotten, then his ghost will forever roam the earth, mourning his miserable fate.

Later, Christian priests accused the filid of encouraging vanity and arrogance in the aristocracy due to over-praise of their virtues. However, the filid and bards believed that praise and care were conducive to doing good deeds and manifesting heroism. At the end of the XVI century, musical and theatrical performances of court Masks were widely distributed and gained popularity in England, the main function of which was to glorify the monarch and immortalize his name, which is actually a copy of the tradition of Irish bards ${ }^{8}$.

\section{The origins of the traditions of the bards}

Gaelic bair or from another Celtic word bardh - Kimra bard. Among the Celts, the word bard was used to refer to a Celtic musician or poet.

In European culture, there are concepts that are largely similar to the concept of "bard": Scandinavian "scops", French "jongleuri", German "gauklers" and "the Minnesingers", noble "troubadours", whose activity was

\footnotetext{
${ }_{8}^{7}$ MacManus S. The Story of the Irish Race. Old Greenwich : Devin-Adair Pub. 1921. 176 p.

${ }^{8}$ Cooper J. Walker Historical Memoirs of The Irish Bards: An Historical Essay On The Dress Of The Ancient And Modern Irish, And A Memoir On The Armour And Weapons Of The Irish. Mishawaka : Palala Press. 2015. 514 p.
} 
associated with southern France, northern Spain and northern Italy, "the trouve're", appeared in the northern and central parts of France and England and was closely related to the traditions of the troubadours, Slavic storytellers, guslars, lirnik and kobzars ${ }^{9}$. The activities of the Hebrew rabbis had some similarities with the Irish bards: the bard and the rabbi performed an educational function, used allegorical and symbolic concepts, and also interpreted music as an important part of the ritual action.

The names of poets, whose work can be indirectly attributed to the work of bards, are found in preserved Greek and Roman literary sources. So, in the poem "Odyssey", whose authorship is attributed to the pen of the ancient Greek poet Homer, there is a mention of two bards and a herald: the divine singer Femius, a performer of poems to the accompaniment of the lyre Demodocus and Medone, a herald in the house of Odyssey.

The great musician Orpheus was "a musician of such strength and sweetness that even wild creatures gathered to listen to him". The sacrificial fate of the poet is a penalty for ancient guilt, for transgressing the border, the veil between worlds ${ }^{10}$. The hero of the ancient Finnish epic "Kalevala" bard Väinomäinen, with the help of divine talent, returned the sun stolen by dark forces to his people.

The ancient pagan gods Dionysus, Apollo, Muse, and Liber were also credited with the patronage of the bards. Among them was the old centaur Chiron, who trained many heroes, among whom, perhaps, was Orpheus. Chiron was considered the source of the art of healing and music ${ }^{11}$.

Irish bards are the guardians of the history and traditions of their nation. The traditions of the bards, their ability to remember, transmit and save verbally the history and customs of their people, are associated with the traditions of the pre-Christian pagan period. So, the tribes living in Europe, which include the Norwegians, Angles, Saxons and Celts, professed a certain pagan worldview on the structure of the world, which was expressed in a system of beliefs, myths and pagan rituals. Encoding and storing this information was vital for the survival of the tribe. Pre-Christian Celtic druids and bards were raised on pagan traditions. Moreover, there were a number of laws that prohibited the transfer of knowledge in writing.

The bard is not only a guardian of traditions, but also a teacher, a prophet, a fortuneteller and a magician, an artist, a servant, and, at the same time, a friend of the king. Richard Kippling wrote about the ancient bard as follows:

"There are nine and sixty ways of reciting tribal lays, And every single one of them is right!" 12

\footnotetext{
${ }^{9}$ Muir F. An Irreverent and Thoroughly Incomplete Social History of Almost Everything. New York : Stein \& Day Pub. 1976. Pp. 16-17.

${ }^{10}$ Dodd G.H. Gynaecology. London : Apottiswoode, Ballantyne \& Co. Ltd. 3rd edition. 1957. P. 155.

${ }^{11}$ Ibid, 178 p.

${ }^{12}$ In the Neolithic Age, Poem of Kipling. URL: http://www.kiplingsociety.co.uk/ poems_neolithic.htm.
} 
Bards were usually professional storytellers. Bards transferred historical, genealogical texts, codes of laws, and even medical texts to poetry. Brehons or bards promulgated laws using recitative style or monotonous singing. Usually the bards were in the open air, on a hill. It is likely that their voices sounded against the background of musical instruments, then the bards were likened to Greek and Roman speakers. Seanachaidhe (bards of advanced age) were patrimonial logisticians and historians. They memorized important events and preserved the genealogies of their patrons in a peculiar poetic form. The impoverished bards appearing in some Irish literary sources were quite rare ${ }^{13}$.

The main function of the bards is not entertaining, but educational. The bards acted as peacekeepers and could keep the army ready for battle from the battle on the battlefield. Bards were especially revered and for the gift of instinctively recognizing in people good and bad qualities that were not obvious to others. The duty of the bards was not only the preservation of traditions, but also their interpretation. Sometimes bards could afford to make judgments on a particular issue. However, in practice, they sought to remain neutral. Many hated the bards for their sharp tongue, capable of destroying the reputation of anyone. The Irish believed in the ability of bards to destroy and even kill using satire ${ }^{14}$.

Bards to a lesser extent were tied to a particular locality or patron. That is why they allowed themselves what the filid did not allow themselves to write - satirical works, rigidly ridiculing aristocrats, and thus, they performed the role of exposers and whistleblowers. The power of the satire of the bard was great and dangerous. There is a legend according to which the king was not hospitable in relation to the bard. Using his gift, the bard composed a satirical poem, after reading which the king was disgraced, crushed and humiliated and forced to abdicate in favor of a more generous person ${ }^{15}$.

After Ireland converted to Christianity, the church banned two pagan rituals that were practiced among the Order of the Bards and were called "bone singing" and "illuminating knowledge". Cad Goddeu (The Battle for the Forest) spoke of the bard's ability to change form and turn into any beast thanks to the gift that the bard received from above ${ }^{16}$. These same abilities were characteristic of the druids, the Magi, and Cossacks-characterists. The bard had the ability to meditate and move in time and space. Going beyond the limits of his own body, he "acquired knowledge first hand," that is, from God.

It was believed that poets received talent from the Higher powers. After the spread and adoption of Christianity in Ireland, it became unacceptable and dangerous to talk about the special magical properties of bards.

\footnotetext{
13 Hore H.F. Irish Brehons and Their Laws Ulster. Journal of Archaeology. Ballycarry: Ulster Archaeological Socie. First Series, Vol. V, 1857. P. 36-52.

${ }_{15}^{14}$ MacManus S. The Story of the Irish Race. Old Greenwich : Devin-Adair Pub. 1921. 109 p.

${ }_{16}^{15}$ Russell J., Cohn R. Cad Goddeu. Warsaw : Book on Demand, Ltd. 2012. 150 p.

${ }^{16}$ Muir F. An Irreverent and Thoroughly Incomplete Social History of Almost Everything. New York : Stein \& Day Pub. 1976. Pp. 16-17.
} 
True bards are almost always masculine. However, one of the main themes permeating the poetry of the bards was the worship of the Goddess and respect for women.

Philosopher poets, no matter what religion or nation they belonged to, treated the church and state power with a feeling of ill-hidden hostility, even if they were kindly affectionate to it. Church and power, in turn, eschewed at best, and at worst, persecuted poets who openly expressed their point of view. Such behavior could be dangerous to the moral health of the state, and poets set a bad example, appealing to the base instincts of human.

Bard schools have been established in different parts of Ireland. As a rule, they were located in the bosom of oak forests and hidden from prying eyes. The most famous schools were founded in Clogher, Armagh and Lismore. The city of Londonderry was originally a famous grove that housed the druid school. Ollam - led the school. The school of bards studied from three to twenty years, the main subjects in the school were poetry, the history of the genealogy of influential Irish clans, playing the harp and other musical instruments. Pupils of bards adhered to a special diet and almost did not eat meat. All entertainment was strictly prohibited. In this way, the bards tried to redirect students to the true values of life. Problems bypassed these places, aggression and envy did not find recognition in these places, genius was cultivated here, and the soul rose ${ }^{17}$.

The surviving documents on the structure of poetry schools shed light on the preparation of poets. The bards had about sixteen different levels of training. Each level has its own status. Each level limited the bard to a certain number of syllable forms. Bards were not allowed to compose in more complex poetic meters belonging to a higher level. Teachers recommended that beginning bards retire to a dark room to compose a poetic composition so as not to be distracted by the bustle and focus on the chosen topic, which helped the poet focus on their chosen topic. Some bards were famous for compositions of elegies of a personal nature, others practiced romantic or religious poetry, including retelling of historical events, genealogies, heroic stories, myths and legends, as well as works of praise and poetry in which they recounted the exploits of leaders and kings. Still others wrote satirical works. Bards composed odes in honor of their patron on the eve of a festive event - Christmas or Easter, wedding, funeral or housewarming. The Ode was performed by a professional reader accompanied by musical accompaniment, while the poet himself sat with the owner at the same table and drank from the same cup ${ }^{18}$.

The bards also studied martial art. Many of the bards could boast of their skill in battle and the ability to handle weapons. The ability to handle

\footnotetext{
${ }^{17}$ Muir F. An Irreverent and Thoroughly Incomplete Social History of Almost Everything. New York : Stein \& Day Pub. 1976. Pp. 19-28.

${ }^{18}$ Cooper J. Walker Historical Memoirs of The Irish Bards: An Historical Essay On The Dress Of The Ancient And Modern Irish, And A Memoir On The Armour And Weapons Of The Irish. Mishawaka : Palala Press. 512 p.
} 
weapons and strike back made bards healthy, agile, strong, and developed their physical stamina. That is why many bards possessed fearlessness and courage, valor, allowing them to be on the battlefield and maintain the spirit of Irish warriors. The Irish despised such human qualities as cowardice and lack of willpower ${ }^{19}$.

The duties of many bards included playing instruments. As a rule, this status was inherited from generation to generation. The ancient Irish cultivated three types of musical compositions, originating from the Greeks, who in turn borrowed them from the Egyptians: Gollttraidheacht, Geanttraidheacht and Suanttraidheacht. The Gollttraidheacht style was used to write holiday songs and dances, to raise morale, to awaken Love and Spring ${ }^{20}$.

The musical compositions, written in the Geanttraidheacht style, were compositions at a slow pace, based on the pentatonic scale. In such compositions, they mourned the loss of loved ones, the death of great people or the injury of heroes.

The specificity of Irish music is in the sinuous sensuality that makes its way to the heart, permeates the whole body, awakens sensitivity, excites or soothes the soul and is capable of influencing a person on a physical level. The music of Ireland is the voice of Nature itself.

Perhaps the "Irish cry", as it is commonly called, is the oldest musical piece ever completed. It is known that female voices poured into the chorus of songs called funeral. Typically, these women were of the lower class. The women were dressed in white or black clothes. The tradition of a female choir participating in the funeral procession has survived to this day ${ }^{21}$.

Irish bards in the sixth century wore long robes edged with gold or silver that covered their feet. Most likely the bards had a long beard and their hair was loose. The bards were allowed to use only five colors in their clothes: white, blue, green, black, and red. The anonymous author of "The Order of St. Patrick", published in 1783, thus describes a bard wearing a green robe lined with gold and a hood adorned with jewels. In such a dress, the bard resembled the king or bards of antiquity wore ${ }^{22}$.

Perhaps, to get an idea of the clothing of the ancient Irish bards, you can take a look at the colorful cloaks of the English in the Middle Ages. Perhaps the colors in the robes of the Bards changed depending on the status of the family to which they belonged. In Shakespeare's time, all the servants of the nobility wore silver badges on their liveries, which were engraved with the hands of their masters.

In $575 \mathrm{AD}$, High King Áed of Slane decided once and for all to end the Irish clan's tradition of patronage of bards. However, the nobility prevented

\footnotetext{
${ }^{19}$ Galloway P. The most illustrious Order: The Order of St Patrick and its knights. London : Unicorn Press, $1999.246 \mathrm{p}$.

${ }^{20}$ Cahill Th. How the Irish Saved Civilization. New York : Doubleday. 1996. 246 p.

${ }_{22}^{21}$ Walker J.C. Historical Memoirs of the Irish Bards. Sydney : Wentworth Press. 2019. 314 p.

${ }^{22}$ Ibid. 
the expulsion of the filid and bards, but some privileges were limited. The Irish monk Saint Columbus, a preacher of Christianity in Scotland, who was considered one of the "twelve apostles of Ireland" and enjoyed great influence in the country, defending the traditions of the bards of Ireland, said that "poetry is an integral part of Irish life" ${ }^{23}$. The influence of the bards was limited by the closure of bard schools, in the place of which monasteries and monastic schools began to form ${ }^{24}$.

However, in general, it can be stated that the attempt to destroy the bards as a class, repeatedly failed. The bards survived and found a grateful audience among some of the Irish aristocracy, monasteries, and roadside inns of medieval Ireland.

In the 5th century, the ideals of Christianity began to spread actively in Ireland. Monks began to write poetry in the margins of manuscripts, thus adopting this tradition from the bards, seizing the initiative and gradually dominating the field of poetry. Joseph Cooper Walker's "Historical Memoirs of the Irish Bards", written in 1786, noted that all the prominent schools that were established by the Christian clergy in the 5th century were located in the places where bard schools were previously located ${ }^{25}$. Since the services of scribes were very expensive in some monasteries, bards lived as genealogists and historians who recorded certain events. Although the Irish monks were fanatical in their zeal to preserve and convey old legends, stories, and lineages to posterity, they continued to share this responsibility with the filid and the bards.

Over time, the bards formed the Order, which constituted a special segment of society. From 1176, bards began to gather in the Soviets, where the Ollams presided. The flourishing of bard poetry fell in the XII-XIII centuries and, in time, actually coincided with the period of the Anglo-Norman conquests. The philosophy of the bards was closely related to Christian dogmas. However, a secular character prevailed in $\mathrm{it}^{26}$.

In the XII century, hereditary bard poets finally lost contact with church schools, as religious orders took obligations to study genealogy, poetry, and law in church schools. Thus, the literary world of the Irish was enriched by the interaction of secular and ecclesiastical poetry ${ }^{27}$.

Medieval Irish poems are unique in terms of complexity of composition and adjustable meter. The language used by medieval bardic poets was the classic early Irish language and had a fixed vocabulary and grammar that had long been used in Ireland and Gaelic-speaking Scotland. O'Cianain

\footnotetext{
${ }^{23}$ Winwood Reade W. The Veil of Isis, or Mysteries of the druids. Boston : Weiser Press. 1992. P. 186.

${ }^{24}$ Harbison P. Pre-Christian Ireland: From the First Settlers to the Early Celts. London : Thames \& Hudson Ltd. 1988. 208 p.

${ }^{25}$ Ibid.

${ }^{26}$ Cooper J. Walker Historical Memoirs of The Irish Bards: An Historical Essay On The Dress Of The Ancient And Modern Irish, And A Memoir On The Armour And Weapons Of The Irish. Mishawaka : Palala Press. 2015.

${ }^{27}$ Winwood Reade W. The Veil of Isis, or Mysteries of the druids. Boston : Weiser Press. 1992. 256 p.
} 
Miscellany, the first Irish treatise for poets on metric shortcomings, was developed in the middle of the 14th century and is kept in the National Library of Ireland ${ }^{28}$.

It was believed that medieval bards belonged to different classes of estates and inherited various privileges from their ancestors. The impoverished bard scholars featured in some Irish literary sources were rare. In the late Middle Ages, upper-class bards served in royal courts, glorified the king, ladies, and fallen warriors, and taught in secular schools that were established in the fourteenth century and functioned until the seventeenth century. High-ranking bards were allowed to have an entourage, which usually included poets and lower-ranking students. Secular families of hereditary bards ran schools of history and poetry. Upper-class bards strove for control and maximum influence over power structures. The lower-class bards entertained the townspeople. Many of them recited romances that became popular thanks to the influence of French culture. There were bards of a special kind who possessed a unique gift and courage, they ridiculed human vices, regardless of their position and status (the prototype of the holy fool among the Slavs). In prose literature, this tradition outlived the bards, and became famous in the work of such Irish writers as Jonathan Swift ${ }^{29}$.

By the XVI century, bards became part of the educated literary men of their time, and the noblest Gaelic families considered it an honor to patronize hereditary bard families. Many great bards had a long lineage ${ }^{30}$ and their careers depended on the intensity of their training. Poets were protected by social taboos ${ }^{31}$. The medieval court bard was respected: it was believed that the poet's poems were endowed with special energetic power ${ }^{32}$. Thus, the aura of mysticism associated with the work of bards endowed them with a special position in society, thanks to which they were exempt from tribute and had a status equal to that of a clergyman. Encroachment on the health and life of a bard in the Middle Ages was equated with the most serious crimes. For all the integrity of the reputation of the filid and bards, some of them were not distinguished by high moral qualities and used their special position for personal gain. There are stories of how the bards blackmailed the Irish nobility with the performance of curse songs and brought trouble to the house of patrons. So, singing the legendary Irish song "Glamdikkin" could lead to blisters on the face, which was a shame. A vilification song, sung publicly by a medieval bard, could significantly degrade the Irishman's status. If a curse was sent to an innocent person, then it was considered unjustified, such a curse

\footnotetext{
${ }^{28}$ Harbison P. Pre-Christian Ireland: From the First Settlers to the Early Celts. London : Thames \& Hudson Ltd. 1988. 208 p.

${ }^{29}$ Cooper J. Walker Historical Memoirs of The Irish Bards: An Historical Essay On The Dress Of The Ancient And Modern Irish, And A Memoir On The Armour And Weapons Of The Irish. Mishawaka : Palala Press. 2015. 514 p.

${ }_{30}$ Reese G. Music in the Middle Ages. Chapter 7, New York : WW Norton \& Co Inc. 1940. 502 p.

${ }^{31}$ Winwood Reade W. The Veil of Isis, or Mysteries of the druids. Boston : Weiser Press. 1992. $256 \mathrm{p}$.

${ }^{32}$ Reese G. Music in the Middle Ages. Chapter 7, New York : WW Norton \& Co Inc. 1940. 502 p. 
passed on to the poet and threatened his mental and physical health. This is the case when in 1601 the court poet Thadhg Mac Dair threatened Red Hugh O'Donnell and called on Heaven to avenge his cattle being plundered by the Ulster army. However, there was no confirmation of Hugh O'Donnell's illegal actions and subsequently Tadhg Mac Dair died in agony ${ }^{33}$. Bards, possessing the dark secrets of magical fortune-telling, encouraged ignorant gullibility and anxious fears of a person, skillfully using and controlling human fears.

Bards can be counted among the cosmopolitans. They traveled with pleasure throughout Ireland and often found themselves outside the country in search of new experiences. The concept of the "wandering bard" has become firmly established in the vocabulary of the Irish. Bards were considered the only reliable source of information at the time.

Medieval bard poetry asserted the sovereignty of the Gaelic lords. Often the poet encouraged his patrons to take action, whether it be a demonstration of military skill, the search for a lady of the heart, or patronage of learned families. As part of their writings, bards gave advice, ridiculed vicious alliances or the behavior of a patron ${ }^{34}$. Bards pursued political goals, defended historical rights, and talked about love. However, bards have always acted in a system of traditional values, which determined their behavior ${ }^{35}$.

The most famous bards in Ireland include Flann McLenana, Eohyde Floyn, McLeagh, Miredach of the Scotsman, Donnaha Mora O'Daley, Far Flach O'Gniva ${ }^{36}$.

One of the most famous bard poets of all time and nations was William Shakespeare. W. Shakespeare was often called "Bard" or "The Swan of Avon", which was an associative image. Swans can fly, and soaring in the sky is an ancient image of poetic activity. The swan is the symbol of the poet. Bards are poets who tell about the lives of heroes, about love and passion, about the history of their nation and their heroes, about defeats and victories, adversity and human fears, about virtues and base instincts. W. Shakespeare, the great connoisseur of human souls, could rightfully be called the English Bard.

\section{The conquest of Ireland by Cromwell and its consequences for the Irish bards}

The Eleven Years War in Britain is a series of conflicts between various political, ethnic, and religious groups in England, Scotland and Ireland.

\footnotetext{
${ }^{33}$ Cooper J. Walker Historical Memoirs of The Irish Bards: An Historical Essay On The Dress Of The Ancient And Modern Irish, And A Memoir On The Armour And Weapons Of The Irish. Mishawaka : Palala Press. 2015. $514 \mathrm{p}$.

34 Кухаренко Ю.В. Полесье и его место в процессе этногенеза славян (По материалам археологических исследований). Полесье: Лингвистика. Археология. Топонимика. Москва. 1968. C. $18-46$.

${ }^{35}$ Harbison P. Pre-Christian Ireland, for additional related information. London : Thames \& Hudson. 1995. $208 \mathrm{p}$.

${ }^{36}$ O Siochru M. God's Executioner: Oliver Cromwell and the Conquest of Ireland. Publisher: Faber and Faber; International Edition. 2008. 336 p.
} 
In 1641, the Catholic Irish, trying to seize control of the English administration in Ireland, revolted and destroyed the Protestant settlers, there were about 4.000 people, which they brutally killed. The British Parliament deliberately and many times increased the death toll in order to demonstrate to England the cunning and cruelty of the Irish. The Irish uprising becomes a tragic and significant event for the Stuart dynasty and for Ireland itself.

Subsequently, the furious Puritan O. Cromwell subjected Ireland to virtual destruction. O. Cromwell justified the innumerable murders of innocent people by political and religious expediency, hiding behind the name of God. In one of his letters, O. Cromwell remarked: "This is God's righteous judgment over barbaric scoundrels, whose hands are soaked in innocent blood $\langle\ldots\rangle$ such actions will prevent bloodshed in the future and this is a sufficient reason for my actions" ${ }^{\text {"37. }}$.

O. Cromwell sincerely believed that the Irish were a danger to England and regarded the Irish as a barbaric and bloodthirsty nation. The goal of O. Cromwell's policy was to suppress Catholicism and seize the lands of Ireland. People were expelled from the cities, priests were physically destroyed, the rest were expelled from the fertile regions of Ireland to the western rocky shores of Clare and Connaught. There is circumstantial evidence that $\mathrm{O}$. Cromwell sent the Irish as slaves to the West Indies ${ }^{38}$.

September 11, 1649 was one of the darkest days in Ireland. The researchers noted that the level of violence of $\mathrm{O}$. Cromwell and his troops during the siege of Drogheda and the subsequent siege of Wexford, even by the standards of the 17th century, could be considered war crimes. Drogheda was considered one of the most fortified cities in Ireland. However, this did not prevent $\mathrm{O}$. Cromwell from suppressing the resistance and seizing the city. O. Cromwell distinguished himself with particular cruelty towards the inhabitants of Ireland. Entering the city with troops, O. Cromwell brutally dealt with the remnants of the Irish military units, and a group of Irishmen barricaded in St. Peter's Church was burnt alive. Cromwell killed a third of the Catholics who lived compactly in Ireland. Most of the victims were soldiers, priests, and civilians. However, some Irish families from the ancient Gaelic clans, thanks to their connections and influence on politicians in England, managed to preserve their ancestral lands ${ }^{39}$.

Servants of the Gaelic lords also fell under the hammer of repression, including the bard poets, who, the British believed, had the power to curse and incite hatred of England in the people. This made them a target for arrest and subsequent execution ${ }^{40}$. There are preserved archival documents in which

\footnotetext{
${ }^{37}$ The Cromwell Association. URL: http://www.olivercromwell.org/wordpress/?page_id=2274.

${ }^{38}$ Davis J.C. Oliver Cromwell (Reputations). London : Bloomsbury Academic, 1st edition. 2001. 243 p.

${ }^{39}$ Wheeler J.S. Cromwell in Ireland. Dublin : Gill \& MacMillan. First edition. 1999. 320 p.

${ }^{40}$ Кухаренко Ю.В. Полесье и его место в процессе этногенеза славян (По материалам археологических исследований). Полесье: Лингвистика. Археология. Топонимика. Москва. 1968. C. $18-46$. 
it was supposed to punish with death or otherwise, harpers, rhymers and bards ${ }^{41}$. From the beginning of the conquest of Ireland, the bards were perceived by the British as "vagrants" without clan and tribe. The Irish nobility, on pain of death, were forbidden to accept bards into their homes.

Unfortunately, Oliver Cromwell's musical preferences did not extend to the Irish harp, leading to the destruction of thousands of Irish harps and the imprisonment or physical destruction of bards and harpers. By the XVIII century, the ancient traditions of bards were undeservedly forgotten, and the surviving bards eked out a miserable existence.

The military actions of $\mathrm{O}$. Cromwell can be attributed to the category of war crimes and explained by a thirst for revenge and religious intolerance. "Even by the standards of time (O. Cromwell) was beyond comprehension, "wrote the historian and researcher of O. Cromwell's military campaign in Ireland, Dr Micheál Ó Siochrú, author of "The Executioner of God"42.

The merciless warrior O. Cromwell was subjected to derogatory criticism from different sides. The British monarchists condemned O. Cromwell for the execution of King Charles I Stuart, and the radicals for betraying the ideals of the revolution. For many, O. Cromwell became a symbol of England, for others - the curse of Ireland.

At the end of the seventeenth century and throughout most of the eighteenth century, most Irish people lived under the criminal laws against Catholics and Presbyterians ("dissenters"). The Irish were not allowed to own a horse worth more than five pounds, hold public office, teach school, build Catholic churches, acquire weapons, or inherit land belonging to Protestants. The result of the forced migration and unmotivated brutality on the part of the British is the further stratification and impoverishment of Irish society, which by the time of the invasion of troops led by O. Cromwell was largely weakened by the numerous raids of the British. Irish aristocrats and commoners alike shared the fate of the exiles. The religion, the Irish language, customs, music, dance, and poetry of the Irish were persecuted and humiliated by the British. However, the massacre of Protestants, victims of Catholic aggression, helped shape Irish identity. An oppressed but proud nation cherished the memory of its history and passed it on to its descendants. The connection with the past becomes unusually strong. This is characteristic of eras of cultural suppression and political disorientation.

\section{Celtic culture, bard traditions and their influence on Ukrainian culture}

Celtic culture and traditions of the bards have had a serious impact on Ukrainian culture and its subsequent development. Celtic names for various objects are found in virtually every modern European language.

\footnotetext{
${ }^{41}$ Wheeler J.S. Cromwell in Ireland. Dublin : Gill \& MacMillan. First edition. 1999. 320 p.

${ }^{42}$ O Siochru M. God's Executioner: Oliver Cromwell and the Conquest of Ireland. Publisher: Faber and Faber; International Edition. 2008. P. 256.
} 
Archaeologists see a connection with the Celtic language in the names of the Danube - Danubius and Dniester - Danastris rivers.

The presence of the Celts on the territory of modern Ukraine has been repeatedly confirmed by archaeological excavations. Archaeological finds were not isolated: archaeologists found Celtic iron and bronze tools, spears, darts, shields, chain mail, treasures of coins of the I-XI centuries in the Pripyat Polesie, the Middle Dnieper and the Northern Black Sea region, in the Tisa river basin. Traces of Celtic culture were also present on the territory of the unrecognized Pridnestrovian Moldavian Republic. The tools of labor of Celtic origin penetrated to the east of Europe thanks to the compact Celtic settlements, later local artisans produced similar tools, imitating the art of the Celts.

Some historians associate the name of the historical and ethnographic region Boykovshchina in Ukraine, located on the northern and southern slopes of the Carpathians, with the generic name of the Celtic tribe of Boyev, who lived in this territory about 2000 years ago. The Boys came here from Bohemia, whose name comes from the Latin Boiohaemum - "the mother's house of the Bois". So, in the Zaporizhzhya Sich, the Cossacks were often called not by name, but by belonging to a particular ethnic group. RusinVerkhovyns who came from the Boykovshchina region, the Cossacks called them Boyki ${ }^{43}$.

The largest ancient settlement of the Celts was located on Mount Lovachka not far from modern Mukachevo, where not only the Celts, but also the highest spiritual caste, the druids, whose sanctuary was located on the top of the mountain, where ancient oaks grew, which had a sacred meaning for the druids. Back in the early twentieth century. In this place, excavations were carried out by a historian, ethnographer, who was considered the founder of archeology and museum affairs in Transcarpathia, Tivodar Legotsky. His numerous finds can be called unique: the remains of fortifications, weapons, jewelry, ceramics, casting, household implements, a mold for coins cast by the Celts. All this is kept in the Uzhgorod Museum of Local Lore and serves as evidence of the presence of the Celts in this area. According to archaeologists, the Botar steppe is also associated with the presence of Celtic tribes in it. The Botar region was considered one of the largest iron-finishing production centers in Europe during the early Iron Age. Mineral resources were estimated in tens of tons of iron and met the needs of a small settlement of Galish-Lovachki, Mukachevsky district of the Transcarpathian region, and Transcarpathia as a whole. The Celtic Metallurgical Center was located in what is now a wetland by the Botar River, a left tributary of the Tisza, and covered about 25 square kilometers. About three hundred iron-smelting furnaces were discovered there. Production centers were built at a distance of

\footnotetext{
${ }^{43}$ Амброз А.К. Фибулы Юга Европейской части CCCP: II в. до н. э. - IV в. н. э. Москва : Наука. 1966. C. 111.
} 
1-2 km from each other and stretched from the village of Klinovo to the village of Cherny ${ }^{44}$.

Researcher. Y. Kukharenko ${ }^{45}$ and A. Amyuroz ${ }^{46}$ came to the conclusion that Celtic settlements could be located not only in the Transcarpathian region, but also in the Carpathian region, where small-sized structures were discovered that the Celts could use both for the production of the necessary utensils, and for housing.

The Celts penetrated inland into the territory of Eastern Europe and mixed with other peoples. Thus, an original culture arose on the territory of Transcarpathia, since the movement of the Celts to other territories led to the mixing of traditions.

The Celts had long mustaches, which later came to be perceived as a sign of militancy and masculinity. The mustache has become a hallmark of the Slavs since the time of Svyatoslav, a symbol of the Zaporozhye Cossacks and an object of their pride.

Some mythological creatures of the Irish folklore have similarities with the characters of Ukrainian folklore. So, Viy, an evil spirit from the underworld, personifying death, could wipe entire villages from the face of the earth with the help of a single, but incinerating, lightning-like glance. Ukrainian Wii is similar to the Irish demon Balor, called the "Evil Eye", for his ability to slay anyone with just one glance ${ }^{47}$.

Red hair has long been associated with the Celts. The ancient Greeks and Romans described the Celts as having amazingly colored hair. Red hair is a phenomenon of northern and central Europe, however, cases of compact residence of redheads are found in the Middle East, Central Asia (especially among Tajiks), in north-western China, in Udmurtia (about $10 \%$ of the population). All these people have a common ancestry with the Celts, which can be traced to the $\mathrm{Y}$-chromosome haplogroup: R1b. It is interesting to note that residents of Malinsky and Korostensky districts of Zhytomyr region differ from other residents of Ukraine in their red hair color and characteristic freckles.

A.V. Galanin in his work "Russians are not Slavs" writes: "The names of cities and regions in Europe speak of the power of the Celtic civilization: Gaul in France and Galicia in Spain, separate tribes of the Celts gave the names of Belgium, Bohemia and Aquitaine. $<\ldots>$ Some scholars believe that Carpathian Galicia is also a fragment of the ancient Celtic civilization, which underwent subsequent Slavicization" ${ }^{\text {"48 }}$.

\footnotetext{
${ }_{44}^{44}$ Укрінформ. URL: https://www.ukrinform.ru/rubric-culture/1910327-teni-zabyityih-keltov.html.

45 Кухаренко Ю.В. Полесье и его место в процессе этногенеза славян (По материалам археологических исследований). Полесье: Лингвистика. Археология. Топонимика. Москва. 1968. C. $18-46$. $111 \mathrm{c}$.

${ }_{46}$ Амброз А.К. Фибулы Юга Европейской части СCCP: II в. до н. э. - IV в. н. э. Моск : Наука. 1966.

${ }_{47}$ Укрінформ. URL: https://www.ukrinform.ru/rubric-culture/1910327-teni-zabyityih-keltov.html.

${ }^{48}$ Галанин А.В. Викинги и варяги-Русь. Начало Руси. URL: http://ukhtoma.ru/history8.htm.
} 
Genetic analysis of the population of Europe leads to the following conclusion: the concentration of Celtic halogroups is especially noticeable in Scandinavia, Iceland, Finland, the former territory of Yugoslavia, Ukraine, Germany, and France.

The Celts and their Irish descendants are carriers of unique traditions, customs, and culture. Consequently, the Celtic original culture took deep roots in the culture of other peoples.

The wandering bard phenomenon has been known since ancient times. In Ukrainian culture, a prominent representative of the bard of national revival was the itinerant philosopher-theologian, Grigoriy Skovoroda, who voluntarily accepted the burden of wandering.

The maiden name of T. Shevchenko's mother is Boyko. Consequently, Ekaterina Yakimovna Shevchenko, nee Boyko, may have been a descendant of the Celts living in the Boykov region. Then this version easily explains the cultural heritage of Taras Shevchenko, who was called the Ukrainian bard during his lifetime, and in whose work Celtic-Irish traditions of rhyming can be traced ${ }^{49}$.

Dmitry Nalivaiko believed that the main ideas and motives in the work of T. Shevchenko are consonant with the ideas of the Irish and Scottish poets of the late Renaissance. In poetry and music, Irish bards raised the idea of national self-sufficiency and identity on the shield, which makes the poetry of T. Shevchenko related to Irish poetry. It is possible to draw a typological parallel between "Kobzar" by Taras Shevchenko and a number of works by the Celtic Renaissance poets (R. Burns, J. McPherson and T. Moore). The poets of the "Celtic spirit" were singers of the national culture, and therefore often turned to early medieval Ireland in the X-XI centuries, since it was during this period that Irish culture flourished. Like the Irish bard-poets T. Shevchenko, he was fond of the history of ancient Ukrainian literature, the culture of Kyivska Rus ${ }^{50}$.

It should be noted that at the end of the XVIII century, the literary movement "Ossianism" was born in Europe, associated with the name of the legendary warrior and bard, the hero of Celtic folklore and Scottish poet J. Macpherson, who wrote the poem "Works of Ossian, son of Fingal", which instantly gained popularity in Europe and America. Ossianism was characterized by an appeal to nature, the incomprehensibility of the secrets of life and death, the greatness of life, the legendary past, the courage of the warriors of antiquity, itinerant singers, and musicians. The hero in D. MacPherson's work is looking for the meaning of life, reflects on the

\footnotetext{
${ }_{50}^{49}$ Зайцев П. Життя Тараса Шевченка. Львів : Наукове товариство ім. Шевченка. 1992.400 с.

50 Наливайко Д.: «До романтизму національної своєрідності мистецтва не існувало». URL: https://zn.ua/ukr/EDUCATION/dmitro-nalivayko-do-romantizmu-nacionalnoyi-svoyeridnosti-mistectva-neisnuvalo-_.html.
} 
mortality of earthly life, and admires the country's past. T. Shevchenko's poetry was consonant with the direction of "Ossianism" in literature ${ }^{51}$.

\section{CONCLUSIONS}

The Irish people have fully preserved the Celtic traditions. The most educated section of society, the Celtic-Irish druidic, filid, and Bardic priests, can be seen as the Holy Trinity in pre-Christian Celtic culture. The spread of Christianity in Ireland led to the gradual leveling of the status of the druids, who were convicted of monstrous crimes - human sacrifice. The Filid assumed the role of spiritual teachers, gradually usurping important ritual and ceremonial functions performed by the druids. The Filid acted as sacred soothsayers.

The influence of the bards on Irish culture in general cannot be overstated. Bards performed a number of key functions, including educational, conciliatory-secular, and religious-bonding functions. Over time, the class of Filid and bards merged into one.

The "masculinity" of the bards was explained by the patriarchal traditions of Irish society and the existence of inheritance laws.

Note that the Christian church and the bards often acted on a single plane, spoke in the language of symbols and allegories, trying to explain everydaybiblical truths. Bards, like Jesus Christ, used parables for edification, as well as to explain complex things in a simple and accessible way.

The poetry of the bards is inherently archaic, but through the prism of Irish mythology and the heroic past of Ireland, the bards were actively looking for parallels in modern events. The language of bard poetry was based on the use of symbols and metaphors, the study of which was part of the curriculum in secular bard schools.

O. Cromwell's military actions led to the beginning of a destructive process that served as a starting point for the disappearance of the bards as a class.

The creativity of the upper-class bards cannot be viewed in the context of an exclusively secular and aesthetic component. It is valuable in the context of "cultural capital".

The once powerful Celtic civilization, and later, the Irish culture, had a huge impact not only on the culture of Western Europe, but also, undoubtedly, on the culture of Kyivska Rus. This is evidenced by numerous archaeological excavations in the territory of Ukraine, and the commonality of some traditions and customs. In the works of the outstanding Ukrainian poet-bard T. Shevchenko, literary techniques and motives characteristic of the poetry of the Irish of the Renaissance are traced.

\footnotetext{
${ }^{51}$ Nut A. Ossian and the Ossianic Literature. Karnataka : Reitell Press. 2008. 80 p.
} 


\section{SUMMARY}

The article examines the traditions of the bards, who were an important symbol of ancient and medieval Ireland. The origins of the concept of "bard" are determined. The characteristic is given to the specific features of the literary language of the poetry of the bards of Ireland. The points of interaction between the poetry of the bards and the Christian church in Ireland are revealed. The functions of bards in Irish society are revealed. The reasons for the decline of the poetry of bards and the actual disappearance of bards as a class by the end of the 17th century are revealed. The creativity of the bards is considered in the context of universal human cultural capital. It is determined that the Celtic-Irish culture influenced the culture of Western Europe and Ukraine. It is emphasized that in the work of Taras Shevchenko, there are Celtic-Irish motives and poetic traditions of bards.

\section{REFERENCES}

1. Grey T. Elegy Written in a Country Churchyard. Charleston : Nabu Press. 2012. 94 p.

2. Cooper J. Walker Historical Memoirs of The Irish Bards: An Historical Essay on The Dress of The Ancient and Modern Irish, And A Memoir on The Armour And Weapons Of The Irish. Mishawaka : Palala Press. 2015. 514 p. ISBN 13: 978-1342418319.

3. Llywelyn M. Bard: The Odyssey of the Irish. New York : Tor Books. 1987. $480 \mathrm{p}$.

4. Greene D. Duanaire Mheig Uidhir: the Poembook of $\mathrm{Cu}$ Chonnacht Mag Uidhir, Lord of Fermanagh 1566-1589. Edited from the Copenhagen. Vol 1. 1991. $307 \mathrm{p}$.

5. Green M.J. Dictionary of Celtic Myth and Legend. London : Thames and Hudson. 1997. 240 p. ISBN-13: 978-0500279755.

6. Carney J. The Irish Bardic Poet: A Study in the Relationship of Poet and Patron as Exemplified in the Persons of the Poet, Eochaidh O Heoghusa (O'Hussey) and ... of Fermanagh. Dublin : Dublin Institute for Advanced Studies. 1985. $40 \mathrm{p}$.

7. MacManus S. The Story of the Irish Race. Old Greenwich : Devin-Adair Pub. 1921. 109 p. ISBN-13: 978-9992469057.

8. Muir F. An Irreverent and Thoroughly Incomplete Social History of Almost Everything. New York : Stein \& Day Pub. 1976. Pp. 16-17.

9. Dodd G.H. Gynaecology. London : Apottiswoode, Ballantyne \& Co. Ltd. 3rd edition. 1957. 178 p.

10. Hore H.F. Irish Brehons and Their Laws Ulster. Journal of Archaeology. Ballycarry: Ulster Archaeological Socie. First Series, Vol. V, 1857. Pp. 36-52. ISBN: 9781378242599. 
11. Russell J., Cohn R. Cad Goddeu. Warsaw : Book on Demand, Ltd. 2012. $150 \mathrm{p}$.

12. Cahill Th. How the Irish Saved Civilization. New York : Doubleday. 1996. $246 \mathrm{p}$.

13. Galloway P. The most illustrious Order: The Order of St Patrick and its knights. London : Unicorn Press, 1999. 246 p.

14. Hast D.E., Cowdery J.R. \& Scott S. Exploring the World of Music. Dubuque, IA: Kendall/Hunt. 1999.

15. Walker J.C. Historical Memoirs of the Irish Bards. Sydney : Wentworth Press. 2019. 314 p.

16. Winwood Reade W. The Veil of Isis, or Mysteries of the Druids. Boston : Weiser Press. 1992. 256 p.

17. Harbison P. Pre-Christian Ireland: From the First Settlers to the Early Celts. London : Thames \& Hudson Ltd. 1988. 208 p.

18. Reese G. Music in the Middle Ages. Chapter 7. New York : WW Norton \& Co Inc. 1940. 502 p.

19. Harbison S. Pre-Christian Ireland, for additional related information. London : Thames \& Hudson. 1995. 208 p.

20. Davis J.C. Oliver Cromwell (Reputations). London : Bloomsbury Academic, 1st edition. 2001. 243 p.

21. Wheeler J.S. Cromwell in Ireland. Dublin : Gill \& MacMillan. First edition. 1999. $320 \mathrm{p}$.

22. Siochru M. God's Executioner: Oliver Cromwell and the Conquest of Ireland.2008 Publisher: Faber and Faber. International Edition. 2008. 336 p.

23. Бідзіля В.І. Історія культури Закарпаття на рубежі нашої ери. Київ : Наукова думка. 1971. 184 с.

24. Кухаренко Ю.В. Полесье и его место в процессе этногенеза славян (По материалам археологических исследований). Полесье: Лингвистика. Археология. Топонимика. Москва. 1968. С. 18-46.

25. Амброз А.К. Фибулы Юга Европейской части СССР: II в. до н. э. IV в. н. э. Москва : Наука. 1966. 111 с.

26. Зайцев П. Життя Тараса Шевченка. Львів : Наукове товариство ім. Шевченка. 1992. 400 с.

27. Nut A. Ossian and the Ossianic Literature. Karnataka : Reitell Press. 2008. $80 \mathrm{p}$.

28. In the Neolithic Age, Poem of Kipling. URL: http:// www.kiplingsociety.co.uk/poems_neolithic.htm.

29. The Cromwell Association. URL: http://www.olivercromwell.org/ wordpress/?page_id=2274.

30. Укрінформ. URL: https://www.ukrinform.ru/rubric-culture/1910327teni-zabyityih-keltov.html. 
31. Галанин A.B. Викинги и варяги-Русь. Начало Руси. URL: http://ukhtoma.ru/history8.htm.

32. Наливайко Д.: «До романтизму національної своєрідності мистецтва не існувало». URL: https://zn.ua/ukr/EDUCATION/dmitro-nalivayko-doromantizmu-nacionalnoyi-svoyeridnosti-mistectva-ne-isnuvalo-_.html.

Information about author:

Sokolova A. V.,

Candidate of Pedagogical Sciences, Senior Lecturer at the Department of Theoretical and Applied Cultural Studies Odessa National A. V. Nezhdanova Academy of Music 63, Novoselskoho str., Odessa, 65023, Ukraine 